\title{
Secondary Tumors of the Prostate
}

\author{
Sekonder Prostat Tümörleri
}

\author{
(D) Havva Erdem \\ Ordu University Faculty of Medicine, Department of Pathology, Ordu, Turkiye
}

\begin{abstract}
In secondary tumors of the prostate, there is an invasion to the prostate directly via lymphatic route or blood circulation. Tumors invading the prostate are defined as adjacent organ tumors. The most common cancers that spread to the prostate are lung cancers.

Especially urothelial tumors may be primary or secondary. Primary or secondary urothelial carcinomas are generally associated with primary prostate adenocarcinoma.

Metastasis should be considered in young patients with a prostate tumor. The aim of this review was to emphasize the importance of prompt diagnosis and early treatment of secondary tumors involving the prostate which are uncommon.
\end{abstract}

Keywords: Prostate, Secondary tumor, İnvasion, Metastasis

\section{Öz}

Prostatın sekonder tümörleri doğrudan invazyonla ya da lenfatik ya da kan dolaşımı yoluyla prostata ulaşan tümörlerdir. İnvazyonla prostata ulaşan tümörler komşu organ tümörleridir. Metastaz ile prostata ulaşan tümörler ise en sık akciğer kanserleridir.

Özellikle ürotelyal tümörler primer ya da sekonder olabilirler. Primer ya da sekonder ürotelyal karsinomlar sıklıkla primer prostat adenokarsinomu ile birliktelik gösterir.

Özellikle genç yaşlarda prostatta tümör varlığında metastazlar akla gelmelidir. Bu derlemede, prostatın nadir görülen sekonder tümörlerinin tanı ve tedavi açısından önemi vurgulanmaktadır.

Anahtar Kelimeler: Prostat, Sekonder tümör, İnvazyon, Metastaz

\section{Introduction}

According to 2018 statistics, prostate cancer is estimated to be the second cancer in men and fifth cancer in the cause of death. In 2018, it was estimated that 1.3 million new prostate cancer (PCa) cases would be diagnosed worldwide and 359.000 cases would result in mortality (1).

Secondary tumors of the prostate are neoplasms that spread directly from the adjacent organs or metastasize from distant areas to the prostate. Bladder and rectal cancers are the most common types of cancer that invade the prostate. Lung carcinomas are the most common metastatic tumors in the prostate. Although rarely, melanoma, tumors of the skin, gastrointestinal tract, penis, thyroid, breast, eye, pancreatobiliary, renal, and laryngotracheal tumors can present with metastasis.
Secondary tumors of the prostate are seen in $0.2 \%$ of male autopsies. In male autopsies with malignancies, this rate is $5.6 \%$, $44 \%$ occurring via direct spread, and $56 \%$ via distant metastasis. It has been demonstrated that the incidence of secondary tumors of the prostate in surgical and biopsy specimens and autopsy specimens was $0.2 \%$. It has been reported that $93 \%$ of secondary tumors of the prostate seen in prostate resections and biopsies were due to direct spread and 7\% were due to distant metastasis (2). The median age is 66 and the range is 39-83 years.

Dissemination pattern is as follows: distant organ metastasis reaching the prostate via arterial dissemination and direct prostate invasion of tumors originating from the urinary bladder or colorectal regions (2).

Correspondence: Havva Erdem MD, Ordu University Faculty of Medicine, Department of Pathology, Ordu, Turkiye

E-mail: drhavvaerdem@gmail.com ORCID-ID: orcid.org/0000-0002-3074-0240

Received: 02.04.2019 Accepted: 25.05.2019

Cite this article as: Erdem H. Secondary Tumors of the Prostate. J Urol Surg 2019;6(4):339-342.

- Copyright 2019 by the Association of Urological Surgery / Journal of Urological Surgery published by Galenos Publishing House. 


\section{Metastatic Solid Tumors of Prostate}

Lungs (49\%), laryngotracheal (2\%), skin (24\%), pancreatobiliary region (9\%), gastrointestinal tract (7\%), kidney, penis, thyroid, breast, and eye are the most common origin of distant solid tumor metastasis (2) (Figure 1).

Tumor markers provide valuable information for diagnosis of the tumor and follow-up. There are studies suggesting that late-relapse of non-seminomatous tumors may occur after 20 years. Relapses may occur in extraordinary locations such as prostate. Information of the primary diagnosis is of the utmost importance in order to get a proper diagnosis. The fact that relapse may occur with a different histologic picture (especially after chemotherapy of yolk sac tumors) and the clinical features may not be typical to the primary tumor and may lead to a histological misinterpretation $(3,4)$.

It has been suggested that the most probable origin of primary melanoma of the prostate was urothelial epithelium of the prostatic urethra. However, in a case with prostatic melanoma, a primary unknown stage 4 tumor cannot be excluded. Autopsy reports indicate that the incidence of prostatic involvement is $3 \%$ in metastatic melanoma. In case of metastatic melanoma, although there is a low chance of cure, radical prostatectomy with extended lymph node dissection may be performed for lower urinary system symptoms. It has been reported that melanomas originating from visceral organs have a low probability of being BRAF- or NRAS-positive when compared with cutaneous melanomas. In addition, it has also been reported that the probability of c-kit mutation was high and, targeted therapy, such as tyrosine kinase inhibition, might be an option in c-kit mutation-positive cases $(5,6)$.
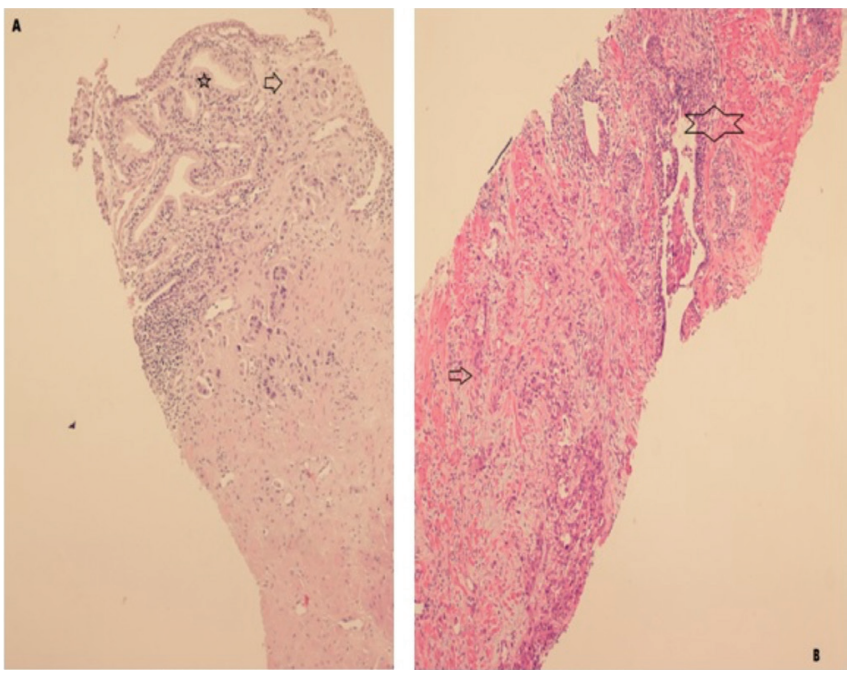

Figure 1. A) Lung adenocarcinoma metastasis (Arrow: Lung adenocarcinoma sites) (Star: Benign prostatic glands) (H\&EX100) B) Colorectal adenocarcinoma metastasis (Arrow: colorectal adenocarcinoma sites) (Star: Benign prostatic glands) (H\&EX100)

\section{Direct Invasion of the Prostate}

Direct invasion of the prostate by urinary bladder carcinomas (85\%), and rectal adenocarcinoma (15\%) is common. In addition to rectal carcinomas, gastrointestinal stromal tumors (GIST) may uncommonly present themselves as a primary prostatic tumor while secondary invasion from rectum to the prostate may also occur (2).

Prostatic urothelial carcinomas may be either primary or secondary from urinary bladder. Prostatic urethral involvement may be associated with invasion from the bladder directly or indirectly (through implantation) (Figure 2). Stromal invasion may occur via submucosal invasion of the prostatic urethra or ductus or spreading along the bladder wall (7).

Prostate-related urothelial cancer was recognized for the first time in 1952 by Melicow and Hallowell and it was defined as Bowen's disease. It is estimated that the incidence of primary urothelial carcinoma of the prostate accounts for $4 \%$ of all prostate malignancies. On the other hand, primary urothelial carcinoma of the prostate is almost always associated with coexisting bladder cancer or carcinoma in situ $(8,9)$.

Poorly-differentiated prostate adenocarcinoma and urothelial carcinoma share overlapping morphologic characteristics in general. It may be challenging to distinguish between these two entities. At the same time, making the distinction may be important in terms of treatment selection and prediction of prognosis. Therefore, immunohistochemical study may be required. Although prostate-specific antigen and prostatic acid phosphatase are traditionally used to confirm a prostatic tumor origin, they may be negative in $27 \%$ and $19 \%$ of patients with poorly-differentiated prostate cancer, respectively. It has been suggested that ERG and NKX3.1 might be useful in the differential diagnosis. Recent studies have supported the suggestion that especially the TMPRSS2/ERG fusion gene is

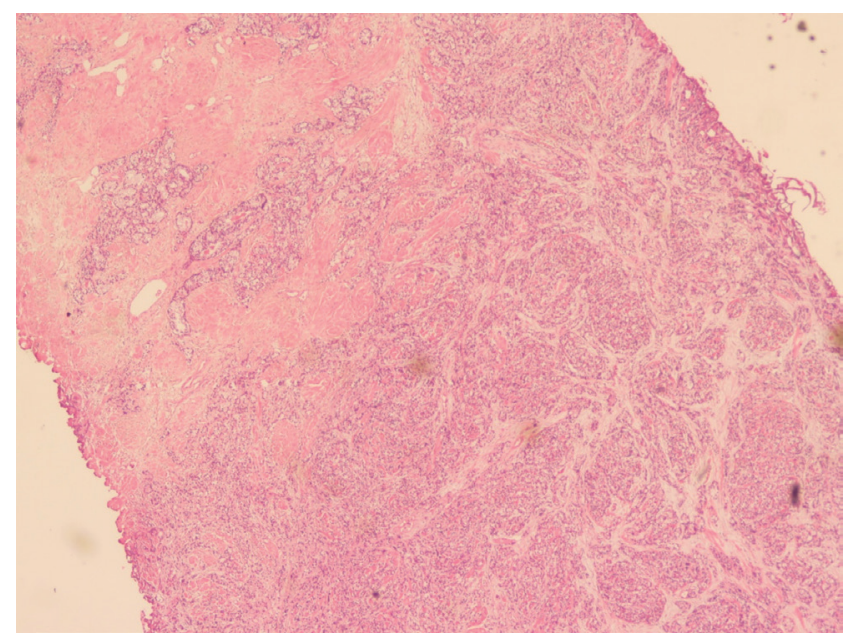

Figure 2. Coexistence of prostatic adenocarcinoma and urothelial carcinoma (H\&EX100) 
present in $50 \%$ of PCa cases (10). NKX3.1 is a prostatic tumor suppressive gene located in chromosome $8 \mathrm{p}$. Although it is positive in most of primary prostatic adenocarcinomas, it has been shown that it is downregulated in high-grade prostate cancers or absent in metastatic ones (in 65\%-78\% of lesions).

Studies have shown that it is highly sensitive and specific for high grade prostatic adenocarcinoma compared with high grade urothelial carcinoma (11).

The frequent coexistence of PCa and bladder cancer may suggest a common carcinogenic pathway. With this approach, Singh et al. (9) have suggested that some tumor suppressive genes may play a significant role in the development of both cancer types. Recently, Amara et al. (12) reported that in most of human urothelial carcinomas, prostate stem cell antigen is overexpressed. However, this finding needs further confirmation, and the model of the common carcinogenic pathway has not been clarified (13).

Androulakakis et al. (14) have suggested that coexistence of PCa and bladder cancer does not have a precise effect on prognosis. Patient prognosis seems to be correlated with the characteristics of each tumor separately.

Recently, a study including 22 patients with vesical urethelial carcinoma associated with prostatic carcinoma, it was reported that the coincidence of bladder urethelial carcinoma and $\mathrm{PCa}$ per se was not an adverse prognostic factor (14).

In addition, some authors have reported that PCA diagnosis may be important for surgery in patients with $\mathrm{pT} 2$ (muscle invasive) bladder cancer. (14).

Although GISTs are the most common primary mesenchymal tumors of the gastrointestinal tract $(70 \%)$, they represent only a small percentage of all gastrointestinal tumors $(<2 \%)$. GISTs are benign and malignant neoplasms staining positively for KIT (CD117) immunohistochemically and originating from Cajal (pacemaker) cells phenotypically. GISTs can be found in any level of the gastrointestinal tract. As the stomach is the most common location (60-70\%), rectal GIST represents only $4 \%$ of all GISTs. When these tumors are localized in the prostate, they may mimic prostate adenocarcinoma clinically. Direct invasion of the prostate by a rectal GIST is uncommon and it may coexist with prostate adenocarcinoma. The differential diagnosis of a rectal GIST with prostate involvement in biopsy samples is based on immunohistochemical assessment primarily and it includes fusiform cell patterns that can affect rectum and prostate and different stromal neoplasms $(15,16)$. In the differential diagnosis, firstly smooth muscle tumors (leiomyoma, leiomyosarcoma) and then, schwannoma, fibromatosis, solitary fibrous tumor and malign melanoma should be included $(15,16)$.
In summary, it should be kept in mind that, although rare, secondary tumors of the prostate may be encountered and it should be kept in mind that it differs from primary prostate tumors in terms of diagnosis and treatment.

In pathologic assessment, clinical findings are of importance in terms of differential diagnosis. If the patient has been diagnosed with an illness earlier, it should be stated in the report. It is also important to note that, for the urothelial carcinomas that are detected in prostate biopsies, the distinction between primary and secondary tumors is only possible with clinical/ radiological classification. For pathologists, secondary tumors should be taken into consideration in the poorly-differentiated malignancies found in biopsies, and the differential diagnosis should be done meticulously.

\section{Acknowledgement}

I would like to thank Prof. Dr. Kutsal Yörüklüoğlu for his contribution and for providing me with archive images.

Peer-review: Externally peer-reviewed.

Financial Disclosure: The authors declared that this study received no financial support.

\section{References}

1. Bray F, Ferlay J, Soerjomataram I, Siegel RL, Torre LA, Jemal A.Global cancer statistics 2018: Globocan estimates of incidence and mortality worldwide for 36 cancers in 185 countries.CA Cancer J Clin 2018;68:394-424.

2. Mahul B. Amin Satish K. Tickoo. Section 3: Prostate Gland \& Seminal Vesicle. Diagnostic Pathology: Genitourinary. 2nd Edition. Elsevier. 2016.pp:708716.

3. Abdelhalim A, El-Hawary AK, Helmy TE, Dawaba ME, El-Baz MA, Elashry R, Hafez AT. Primary Yolk Sac Tumor of the Prostate in a Child: Case Report. Clin Genitourin Cancer 2016;14:e535-e537.

4. Janowitz T, Welsh S, Warren AY, Robson J, Thomas B, Shaw A, Ainsworth NL, Neal DE, Mazhar D. Prostatic relapse of an undifferentiated teratoma 24 years after orchidectomy. BMC Res Notes 2015;8:524.

5. Tosev G, Kuru TH, Huber J, Freier G, Bergmann F, Hassel JC, Pahernik SA, Hohenfellner $M$, Hadaschik BA. Primary melanoma of the prostate: case report and review of the literature. BMC Urology 2015;15:68.

6. Dailey VL, Hameed 0. Blue nevus of the prostate. Arch Pathol Lab Med 2011;135:799-802.

7. Ayyathurai R, Gomez P, Luongo T, Soloway MS, Manoharan M. Prostatic involvement by urothelial carcinoma of the bladder: clinicopathological features and outcome after radical cystectomy. BJU Int 2007;100:10211025.

8. Autorino R, Di Lorenzo G, Damiano R, Giannarini G, De Sio M, Cheng L, Montironi R. Pathology of the prostate in radical cystectomy specimens: a critical review. Surg Oncol 2009;18:73-84.

9. Singh A, Jones RF, Friedman H, Hathir S, Soos G, Zabo A, Haas GP. Expression of p53 and pRb in bladder and prostate cancers of patients having both cancers. Anticancer Res 1999;19:5415-5417.

10. Ayala G, Frolov A, Chatterjee D, He D, Hilsenbeck S, Ittmann M. Expression of ERG protein in prostate cancer: variability and biological correlates. Endocr Relat Cancer 2015;22:277-287. 
11. Gurel B, Ali TZ, Montgomery EA, Begum S, Hicks J, Goggins M, Eberhart CG, Clark DP, Bieberich CJ, Epstein JI, De Marzo AM. NKX3.1 as a marker of prostatic origin in metastatic tumors. Am J Surg Pathol 2010;34:1097-1105.

12. Amara N, Palapattu GS, Schrage M, Gu Z, Thomas GV, Dorey F, Said J, Reiter RE. Prostate stem cell antigen is overexpressed on human transitional cell carcinoma.Cancer Res. 2001;61:4660-4665.

13. Genega EM, Hutchinson B, Reuter VE, Gaudin PB. Immunophenotypeof high-grade prostatic adenocarcinoma and urothelial carcinoma. Mod Pathol 2000;13:1186-1191.
14. Androulakakis PA, Schneider HM, Jacobi GH, Hohenfellner R. Coincident vesical transitional cell carcinoma and prostatic carcinoma: clinical features and treatment. Br J Urol 1986;58:153-156.

15. Anagnostou E, Miliaras D, Panagiotakopoulos V. Diagnosis of Gastrointestinal Stromal Tumor (GIST) on Transurethral Resection of the Prostate: A Case Report and Review of the Literature. Int J Surg Pathol 2011;19:632-636.

16. Laura Macías-Garcia, Haydee De la Hoz-Herazo, Antonio Robles-Frías, María J Pareja-Megía, Juan López-Garrido, José I López. Collision tumour involving a rectal gastrointestinal stromal tumour with invasion of the prostate and a prostatic adenocarcinoma. Diagn Pathol 2012;7:150. 